\title{
Orbital precession modulates interannual rainfall variability, as recorded in an Early Pleistocene speleothem
}

\author{
Philip J. Hopley ${ }^{1}$, Graham P. Weedon², Chris M. Brierley ${ }^{3}$, Christopher Thrasivoulou ${ }^{4}$, Andy I.R. Herries ${ }^{5,6}$, Ada Dinckal ${ }^{5}$, \\ David A. Richards ${ }^{7}$, Dan C. Nita ${ }^{7,8}$, Randall R. Parrish ${ }^{9,10}$, Nick M. W. Roberts ${ }^{10}$, Diana Sahy ${ }^{10}$ and Claire L. Smith ${ }^{11}$ \\ ${ }^{1}$ Department of Earth and Planetary Sciences, Birkbeck, University of London, Malet Street, London WC1E 7HX, UK \\ ${ }^{2}$ Met Office, Maclean Building, Benson Lane, Crowmarsh Gifford, Wallingford, Oxfordshire OX10 8BB, UK \\ ${ }^{3}$ Environmental Change Research Centre, Department of Geography, University College London, Gower Street, London WC1E 6BT, UK \\ ${ }^{4}$ Department of Cell \& Developmental Biology, University College London, University Street, London WC1E 6JJ, UK \\ ${ }^{5}$ Department of Archaeology and History, LaTrobe University, Melbourne Campus, Bundoora, Victoria 3086, Australia \\ ${ }^{6}$ Centre for Anthropological Research, University of Johannesburg, Bunting Road Campus, Auckland Park 2092, South Africa \\ ${ }^{7}$ School of Geographical Sciences, University of Bristol, University Road, Bristol BS8 1SS, UK \\ ${ }^{8}$ Faculty of Environmental Science and Engineering, Babeş-Bolyai University, Strada Fântânele, Cluj-Napoca 400000, Romania \\ ${ }^{9}$ School of Earth and Environmental Sciences, University of Portsmouth, Portsmouth P01 3QL, UK \\ ${ }^{10 N E R C ~ I s o t o p e ~ G e o s c i e n c e ~ L a b o r a t o r y, ~ B r i t i s h ~ G e o l o g i c a l ~ S u r v e y, ~ K e y w o r t h, ~ N o t t i n g h a m ~ N G 12 ~ 5 G G, ~ U K ~}$ \\ ${ }^{11}$ Department of Geography, University of Leicester, University Road, Leicester LE1 7RH, UK
}

\section{ABSTRACT}

Interannual variability of African rainfall impacts local and global communities, but its past behavior and response in future climate projections are poorly understood. This is primarily due to short instrumental records and a lack of long high-resolution palaeoclimate proxy records. Here we present an annually resolved 91,000 year Early Pleistocene record of hydroclimate from the early homininbearing Makapansgat Valley, South Africa. Changes in speleothem annual band thickness are dominated by precession over four consecutive orbital cycles with strong millennial-scale periodicity. The frequency of interannual variability (2.0-6.5 yr oscillations) does not change systematically, yet its amplitude is modulated by the orbital forcing. These long-term characteristics of interannual variability are reproduced with transient climate model simulations of water balance for South Africa from the Late Pleistocene to Recent. Based on these results, we suggest that the frequency of interannual variations in southern African rainfall is likely to be stable under anthropogenic warming, but that the size of year-to-year variations may increase. We see an orbitally forced increase in the amplitude of interannual climate variability between $1.8 \mathrm{Ma}$ and $1.7 \mathrm{Ma}$ coincident with the first evidence for the Acheulean stone tool technology.

\section{INTRODUCTION}

Year-to-year variations in rainfall patterns in eastern and southeastern Africa are influenced by dominant modes of climate variability (Christensen et al., 2013) such as the El Niño/Southern Oscillation (ENSO; Cai et al., 2015) and the Indian Ocean Dipole (IOD; Saji et al., 1999). Substantial effort has been devoted to understanding the past (Tudhope et al., 2001; Emile-Geay et al., 2016) and future (Cai et al., 2015) behavior of these climate modes. However, there are additional long-term influences on African interannual rainfall variability, including sea-surface temperature (Nicholson, 2000; Wolff et al., 2011) and orbital precession (Clement et al., 2004). Instrumental records are too short to provide insights into modes of interannual climate variability, whose properties often vary on centennial time scales (Wittenberg, 2009). This leads to a reliance on proxy records (typically of less than $1000 \mathrm{yr}$ ) of past interannual variability from tree rings (Fowler et al., 2012), corals (Tudhope et al., 2001; Cobb et al., 2013; Emile-Geay et al., 2016), varves (Moy et al., 2002) and annually layered speleothems (Rasbury and Aharon, 2006).
Speleothem time series of annual band thickness of up to $1000 \mathrm{yr}$ duration have been obtained from Holocene African stalagmites (Brook et al., 1999; Baker et al., 2010). The length of these records has been limited by the sporadic preservation of annual laminae and reliance on manual band counting and measuring.

\section{METHODS AND RESULTS}

Here we present a replicated record of band thickness measurements from an Early Pleistocene flowstone from Buffalo Cave, South Africa (Fig. 1A). The flowstone is $2.4 \mathrm{~m}$ thick, horizontally laminated, and exposed at the base of a mined paleo-cave sequence (Hopley et al., 2007). Fluorescent bands were imaged using confocal microscopy (Fig. 1B; see the GSA Data Repository ${ }^{1}$ ). Two parallel grayscale lines from the same interval (Fig. 1B, Line 1 with 91,015 laminae and Line 2 with 91,502 laminae) were extracted from the photomosaic image and automated methods were used to count and measure the bands (see the Data Repository; Fig. DR1). We performed time-series analysis using smoothed periodograms derived using the Lomb-Scargle method applied to both the speleothem lamina data and the CCSM3 (Community Climate System Model) Transient Climate Evolution model (TraCE) simulation (Liu et al., 2014). Significant spectral peaks were distinguished from the power-law background exceeding the $1 \%$ false-alarm level (see the Data Repository for further details). Radiometric and magnetostratigraphic dating techniques are not sufficiently precise for the Early Pleistocene to resolve the annual nature of the laminae (see Figs. DR5-DR7). However, assuming that the laminae are annual and complete, the time interval covered by the laminae is the same as that derived independently from half-precession tie-points from a co-located oxygen isotope data set (Hopley et al., 2007; Fig. DR2). In addition, similar laminae from an Early Holocene flowstone from the same cave are demonstrably annual (Figs. DR3 and DR4). The absolute age of the Early Pleistocene flowstone interval is inferred to be between 1.81 Ma and 1.72 Ma from orbital tuning of the oxygen isotopes (Hopley et al., 2007).

${ }^{1}$ GSA Data Repository item 2018267, additional information on chronology, climate controls on annual band thicknesses, model/data comparison, and the links between climate variability and hominin evolution, is available online at www .geosociety.org/pubs/ft2018.htm, or on request from editing @ geosociety.org. The annual band thickness datasets are archived at the British Geological Survey (BGS) National Geoscience Data Centre (NGDC): http://dx.doi.org/10.5285/59750e40 -ac38-4321-ad74-f001a03ebd16. 


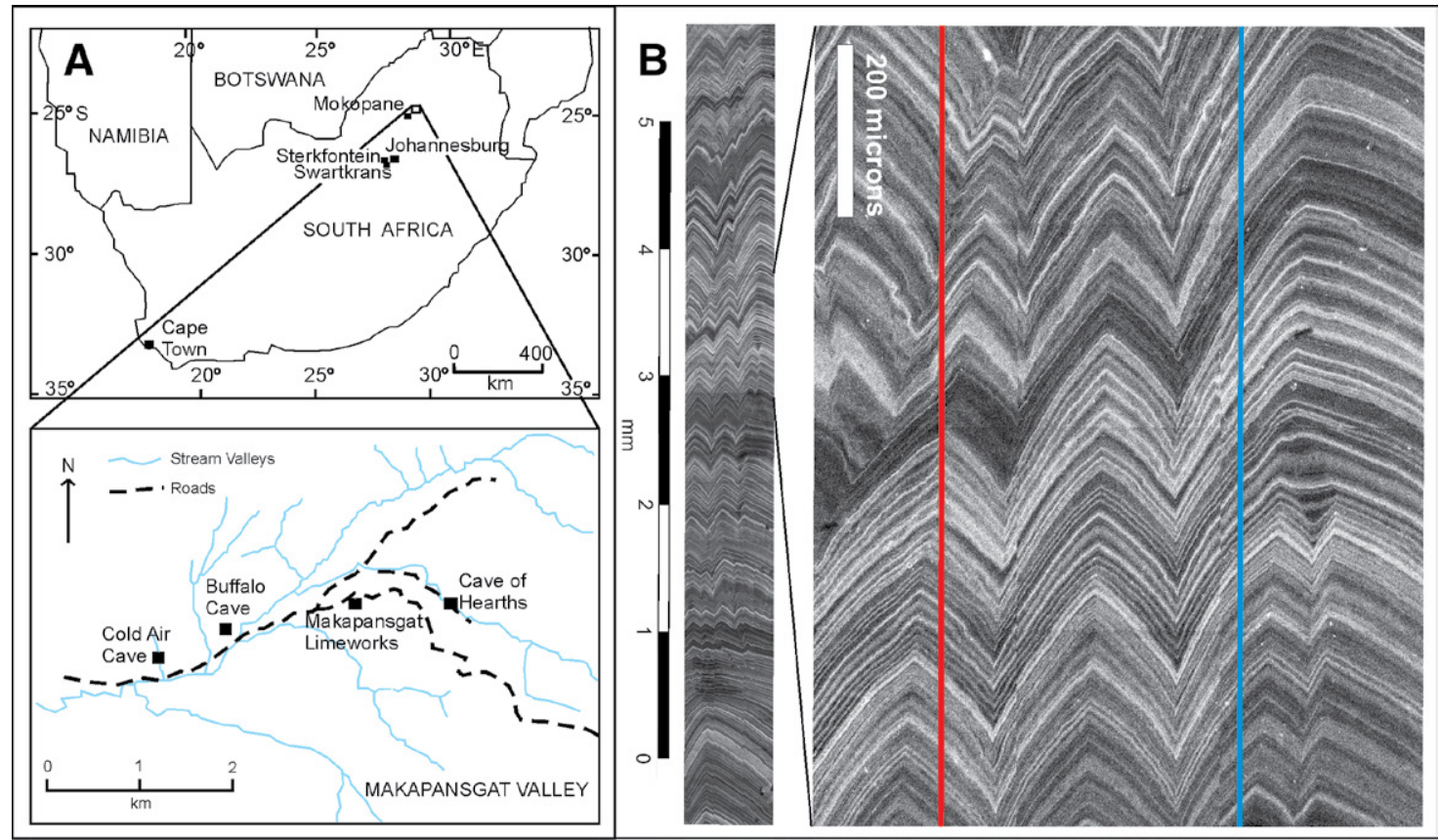

Figure 1. Buffalo Cave, South Africa, and the annually laminated Buffalo Cave flowstone. A: Map of key fossil-bearing caves in the South African "Cradle of Humankind" UNESCO (United Nations Educational, Scientific and Cultural Organization) World Heritage site, including an enlargement of the Makapansgat Valley showing Buffalo Cave. B: Photomosaic of a $6.5 \mathrm{~mm}$ section of the Buffalo Cave flowstone showing the UVfluorescent annual laminae imaged using confocal microscopy. In total, $628 \mathrm{~mm}$ of laminated flowstone was imaged in this study, yielding 91,000 annual laminae. Average band thickness is $6.82 \mu \mathrm{m}$. The replicate lines are shown in red (Line 1) and blue (Line 2).

The processes that determine the thickness of each individual lamina cannot be determined through direct observation, as the flowstone is no longer active, nor is the mined paleo-cave available for cave-monitoring studies. However, the active speleothems in Cold Air Cave $(1 \mathrm{~km}$ southwest of Buffalo Cave; Fig. 1A) are sensitive to seasonal changes in rainfall (Finch et al., 2001) and to regional climatic variability (Sundqvist et al., 2013). Present-day variations in annual speleothem growth rates in this region depend primarily on water availability (Green et al., 2015). We consider variations in the Buffalo Cave lamina thickness to reflect the changing net water budget (precipitation minus potential evapotranspiration), primarily during austral summer (see the Data Repository for a discussion).

The two Early Pleistocene laminae thickness time series have power spectra with gently sloping backgrounds (i.e., following power laws; Figs. 2A and 2B), consistent with the properties of long records of measured precipitation (Fleming, 2013). Identification of regular cyclicity was based on the presence of spectral peaks, at the same frequency for both Lines 1 and 2, which exceed the 1\% "false-alarm level" (see the Data Repository). Spectral peaks denoting cycles of periods of $\sim 23$ k.y. (Figs. $2 \mathrm{~A}$ and $2 \mathrm{~B}$ ) are consistent with orbital-precession forcing, as demonstrated previously for mean climate at Buffalo Cave (Hopley et al., 2007). Low-pass-filtered laminae thickness data for Lines 1 and 2 show 23 k.y. oscillations that are approximately in phase and have relative amplitude variations similar to the orbital precession (Figs. 3B and 3C).

\section{DISCUSSION}

Significant spectral peaks denoting cyclicity of $\sim 4.3$ and $\sim 1.3$ k.y. are recorded for Lines 1 and 2 (Figs. 2A and $2 \mathrm{~B}$ ). The periods of these peaks are similar to the $4.0-2.5 \mathrm{k} . \mathrm{y}$. and $1.25-0.75 \mathrm{k} . \mathrm{y}$. cycles observed in the Late Pleistocene to Holocene $\delta^{18} \mathrm{O}$ record of the nearby Cold Air Cave (see Fig. 1) speleothems (Holmgren et al., 2003). Millennial-scale climate cycles with periods of $1.5 \mathrm{k} . \mathrm{y}$. in the North Atlantic (Dansgaard-Oeschger events) have been demonstrated in the Late Pleistocene and Holocene (Bond et al., 1997). Similar climate cycles have been documented for many terrestrial temperature and hydrological (wet-dry) indicators (Wang et al., 2005). Such rapid climate changes are connected to variations in the thermohaline circulation controlled by meltwater pulses, and are known to modulate the strength of interannual variability (Liu et al., 2014; Turney et al., 2004).

Unlike ENSO temperature-related records from the Pacific (Tudhope et al., 2001; Rasbury and Aharon, 2006; Cobb et al., 2013; Emile-Geay et al., 2016), here we see no robust concentrations of variance in the $2-7 \mathrm{yr}$ band
(Figs. 2A and 2B) in the Early Pleistocene. Generation of low-resolution power spectra using the Bartlett method, using subsections $1000 \mathrm{yr}$ long, demonstrates that the lack of concentrated power at these time scales is not an artifact of the exceptionally high-frequency resolution of the spectra in Figures 2A and 2B (see the Data Repository for methods; Fig. DR8). Similarly, there are no such concentrations of variance at the 2-7 yr scale in instrumental records of South African rainfall (Kane, 2009), Late Holocene corals from Madagascar (Zinke et al., 2004), the Early Holocene laminae record from Buffalo Cave (Fig. 2C), nor within the net water budget in South Africa for the past 22 k.y. from TraCE (Liu et al., 2014) (Fig. 2D).

The replicate time series were high-pass filtered with a cut off at 6.5 yr to extract interannual variability (Fig. 3), as well as band-pass filtered to extract decadal variability with periods of between 10 and $28.5 \mathrm{yr}$ (Fig. DR9). The average period of both the interannual and decadal variability in $100 \mathrm{yr}$ intervals appears to change randomly around a mean; there is no indication of orbital forcing (Fig. 3; Fig. DR9). In contrast, there are large long-term (>1000 yr) changes of the amplitude in both frequency bands, which become more prominent in the later portion of the record (Figs. 3D and 3F). The TraCE simulation (Liu et al., 2014) for the past $22 \mathrm{k} . y$. of summer water balance in South Africa shows similar long-term constancy of the period of interannual variations, but long-term changes in amplitude (Fig. 3).

The apparent discrepancy between the early $21^{\text {st }}$ Century slowdown of rising tropical surface temperatures and climate model projections has been attributed to multi-decadal variability being undersampled by models (Kosaka and Xie, 2013). The Buffalo Cave record suggests that the amplitude of decadal climate variability is underestimated in the TraCE simulation (Figs. DR10 and DR11), as implied by the instrumental record (Laepple and Huybers, 2014). Very long, annually resolved paleoclimate records, such as presented here, provide further insight into multidecadal variability and, in turn, better representation in climate models.

Previous paleoclimate (Tudhope et al., 2001; Moy et al., 2002; Conroy et al., 2008; Koutavas and Joanides, 2012; Carré et al., 2014) and modeling (Clement et al., 2000; Timmermann et al., 2007; Zheng et al., 2008) studies have found a reduction in the frequency and/or amplitude of interannual variability during the mid-Holocene boreal autumn insolation maximum, although recent studies (Cobb et al., 2013; Emile-Geay et al., 2016) have suggested that the link between interannual variability and precession can be masked by large millennial-scale changes. In contrast to these discontinuous proxies, the Buffalo Cave record clearly shows both orbital and millennial-scale changes in the amplitude of interannual 

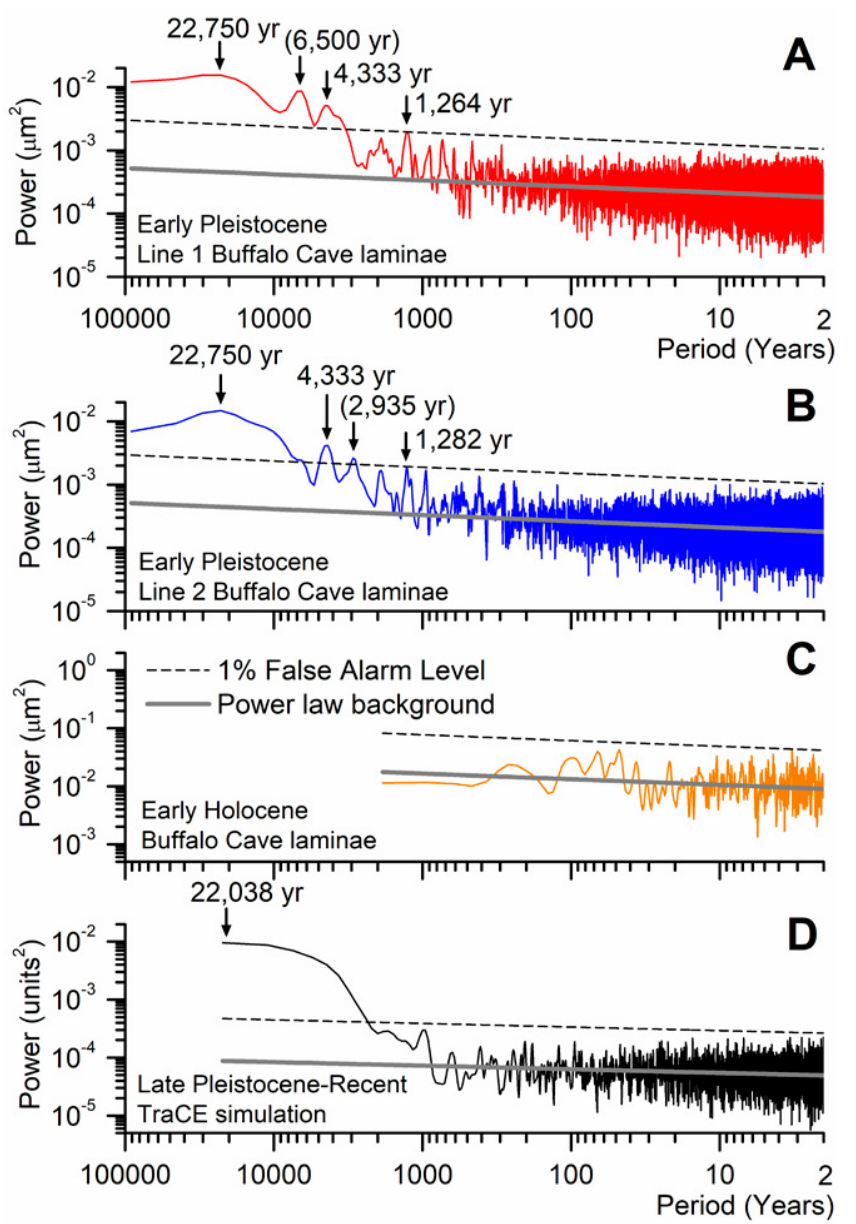

Figure 2. Spectral properties of the hydroclimate time series of (A) Buffalo Cave Line 1, (B) Buffalo Cave Line 2, (C) Early Holocene, and (D) Transient Climate Evolution model (TraCE) simulation, showing power spectra of laminae thickness time series, background power-law fit (gray line), and 1\% false-alarm level (dashed black line). Significant spectral peaks above the false-alarm level are labeled with the corresponding period. Spectral peaks that are not replicated in Lines 1 and 2 are shown in brackets. The spectral peak at $1282 \mathrm{yr}$ for Line 2, although just below the false-alarm level, nevertheless may confirm the reliability of the 1264 yr peak for Line 1.

rainfall variability. However, an ensemble of climate model simulations of Last Glacial Maximum (LGM) to recent rainfall anomalies suggest that the present-day teleconnection between ENSO and southern African rainfall is not robust to changes in orbital forcing (Fig. DR12), explaining the lack of variance in the $2-7 \mathrm{yr}$ band seen in the region (Fig. 2). Therefore, the Buffalo Cave record of rainfall variability should not be viewed as a proxy for ENSO amplitude, but rather represents a local hydroclimate response.

There is an increased amplitude of interannual variations at ca. 1.775 $\mathrm{Ma}$ (Fig. 3F) that is temporally coincident with the emergence of the Acheulean lithic technology (Fig. 3A; see the Data Repository for a discussion). The increased amplitude (Fig. 3B) may be a consequence of the shift to larger precession changes (Clement et al., 2004), but could also be plausibly linked to an enhancement of the tropical circulation at ca. 1.8 Ma (Ravelo et al., 2004; Hopley et al., 2007).

\section{CONCLUSIONS}

It is still an open question as to what effect future anthropogenic climate change will have on tropical climate variability. Model simulations of the $21^{\text {st }}$ Century do not show robust changes in either the frequency or dynamics of interannual variability, such as ENSO (Collins et al., 2010; Stevenson, 2012); however, there are robust amplitude increases in their

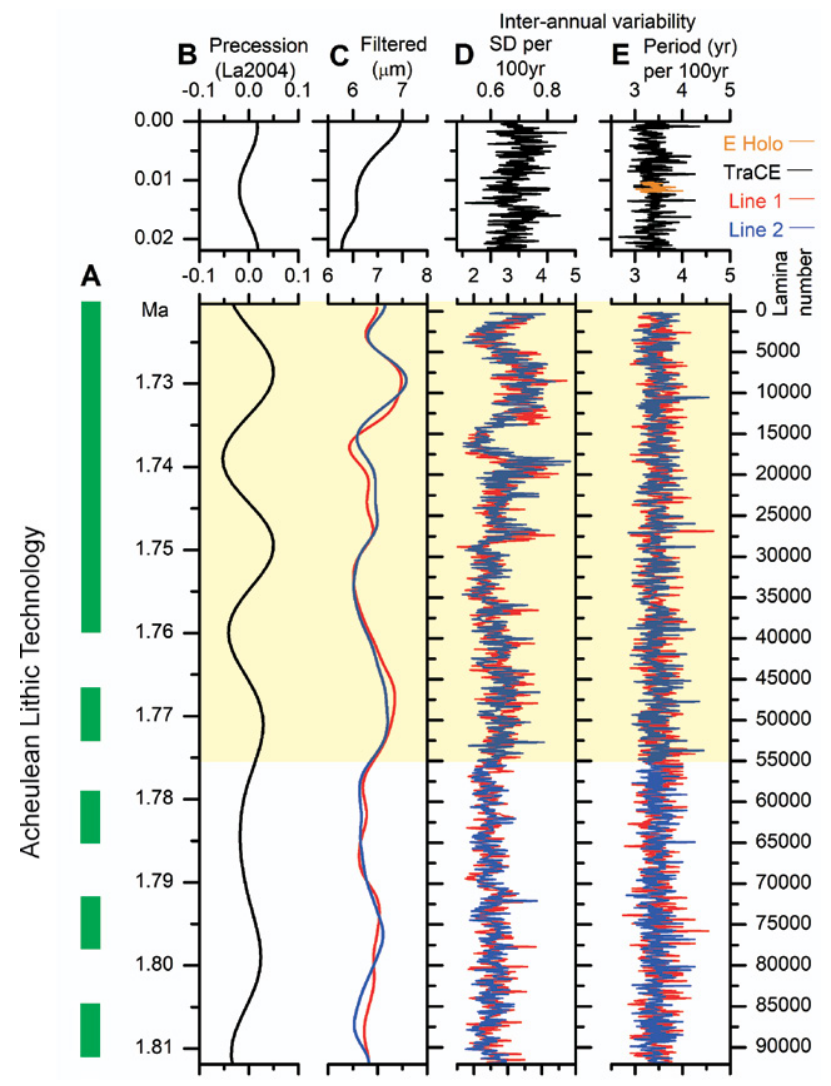

Figure 3. Comparison of interannual variability with orbital-scale changes in South African hydroclimate from Early Pleistocene and Early Holocene flowstone laminae and transient model simulations (Liu et al., 2014), using interannual filters on $100 \mathrm{yr}$ intervals. A: Earliest evidence for the Acheulean (Antón et al., 2014) lithic technology (solid green bar), and the $95 \%$ confidence interval on the first appearance datum (dashed green bar; see Data Repository). B: Orbital precession (La2004-Laskar et al., 2004). C: Low-passfiltered Buffalo Cave laminae from the Early Holocene (E Holo, orange) and Early Pleistocene Line 1 (red) and Line 2 (blue). D,E: Transient Climate Evolution model (TraCE) simulation (black) standard deviations (SD, $\mathrm{mm} /$ day) and period for non-overlapping 100 yr intervals; interannual variations in laminae thickness based on band-pass and high-pass filtering, respectively. SD is between 2 and $4 \mu \mathrm{m}$ from the long-term mean of $6.89 \mu \mathrm{m}$. The standard deviations in $100 \mathrm{yr}$ intervals of the Early Holocene laminae lie beyond the range shown for the TraCE simulation. Increase in the amplitude of interannual variability first occurs at ca. $1.775 \mathrm{Ma}$ (yellow shading).

hydroclimatic response (Fig. DR 13; Cai et al., 2015). Along with increasing extreme floods and drought, this is a simple response to the higher saturation vapor pressure of warmer air (Christensen et al., 2013). Orbital variations are known to change the circulation, temperature, and hydroclimate of subtropical Africa (Joussaume et al., 1999). This new record demonstrates that past interannual hydroclimate variability was controlled, at least in part, by local temperatures (associated with increased local solar insolation). It provides robust observational confirmation of the expected long-term increase in the amplitude of South African rainfall variability during anthropogenic warming (Christensen et al., 2013).

It has been suggested that long-term climate changes influenced morphological and technological change in hominin evolution (Antón et al., 2014). The development of plausible mechanisms for this influence has been hampered by a lack of knowledge about how those long-term climate changes were manifested during an individual's lifespan. This record (and others developed using the novel method described here) could provide essential data for exploring the role, if any, that climate variability and resource uncertainty played in hominin evolution. 


\section{ACKNOWLEDGMENTS}

We thank Mark Maslin for reading the manuscript and for supporting this project from its initiation. Thanks to Steve Noble for technical support at NERC Isotope Geosciences Laboratories and to Ming Tan and two anonymous reviewers for their constructive comments. Funding was provided to Hopley by the Natural Environment Research Council (NERC, UK), awards NE/J00443X/1 and IP/1065/1108. Weedon was supported by the Joint UK DECC/Defra Met Office Hadley Climate Centre Programme (GA01101). Herries was supported by Australian Research Council Future Fellowship FT120100399. Brierley is grateful to the substantial effort of the TraCE modeling and the Paleoclimate Modelling Intercomparison Project (PMIP) modeling groups, who have kindly donated all the simulation output. TraCE-21ka was made possible by the U.S. Department of Energy (DOE) INCITE computing program, and supported by the National Center for Atmospheric Research (NCAR), the U.S. National Science Foundation $\mathrm{P} 2 \mathrm{C} 2$ program, and the DOE Abrupt Change and EaSM programs.

\section{REFERENCES CITED}

Antón, S.C., Potts, R., and Aiello, L.C., 2014, Evolution of early Homo: An integrated biological perspective: Science, v. 345, p. 1-13, https://doi.org/10.1126/science 1236828 .

Baker, A., Asrat, A., Fairchild, I., Leng, M., Thomas, L., and Widmann, M., 2010, Decadal-scale rainfall variability in Ethiopia recorded in an annually laminated, Holocene-age, stalagmite: The Holocene, v. 20, p. 827-836, https://doi.org/10 $.1177 / 0959683610365934$

Bond, G., Showers, W., Cheseby, M., Lotti, R., Almasi, P., deMenocal, P., Priore, P., Cullen, H., Hajdas, I., and Bonani, G., 1997, A pervasive millennial-scale cycle in North Atlantic Holocene and glacial climates: Science, v. 278, p. 1257-1266, https://doi.org/10.1126/science.278.5341.1257.

Brook, G.A., Rafter, M.A., Railsback, L.B., Sheen, S.-W., and Lundberg, J., 1999, A high- resolution proxy record of rainfall and ENSO since AD 1550 from layering in stalagmites from Anjohibe Cave, Madagascar: The Holocene, v. 9, p. 695-705, https://doi.org/10.1191/095968399677907790.

Cai, W., et al., 2015, ENSO and greenhouse warming: Nature Climate Change, v. 5, p. 849-859, https://doi.org/10.1038/nclimate2743.

Carré, M., Sachs, J.P., Purca, S., Schauer, A.J., Braconnot, P., Falcon, R.A., Julien, M., and Lavallée, D., 2014, Holocene history of ENSO variance and asymmetry in the eastern tropical Pacific: Science, v. 345, p. 1045-1048, https://doi.org/10 .1126/science. 1252220

Clement, A.C., Seager, R., and Cane, M.A., 2000, Suppression of El Niño during the Mid- Holocene by changes in the Earth's orbit: Paleoceanography, v. 15, p. 731737, https://doi.org/10.1029/1999PA000466.

Clement, A.C., Hall, A., and Broccoli, A.J., 2004, The importance of precessional signals in the tropical climate: Climate Dynamics, v. 22, p. 327-341, https://doi .org/10.1007/s00382-003-0375-8.

Christensen, J.H., et al., 2013: Climate phenomena and their relevance for future regional climate change, in Stocker, T.F., et al., eds., Climate Change 2013: The Physical Science Basis. Contribution of Working Group I to the Fifth Assessment Report of the Intergovernmental Panel on Climate Change: Cambridge, UK, Cambridge University Press.

Cobb, K.M., Westphal, N., Sayani, H.R., Watson, J.T., Di Lorenzo, E., Cheng, H., Edwards, R.L., and Charles, C.D., 2013, Highly variable El Niño-Southern Oscillation throughout the Holocene: Science, v. 339, p. 67-70, https://doi.org/10 $.1126 /$ science. 1228246

Conroy, J.L., Overpeck, J.T., Cole, J.E., Shanahan, T.M., and Steinitz-Kannan, M., 2008, Holocene changes in eastern tropical Pacific climate inferred from a Galápagos lake sediment record: Quaternary Science Reviews, v. 27, p. 1166-1180, https:// doi.org/10.1016/j.quascirev.2008.02.015.

Collins, M., et al., 2010, The impact of global warming on the tropical Pacific Ocean and El Nino: Nature Geoscience, v. 3, p. 391-397, https://doi.org/10.1038/ngeo868.

Emile-Geay, J., et al., 2016, Links between tropical Pacific seasonal, interannual and orbital variability during the Holocene: Nature Geoscience, v. 9, p. 168-173, https:// doi.org/10.1038/ngeo2608.

Finch, A.A., Shaw, P.A., Weedon, G.P., and Holmgren, K., 2001, Trace element variation in speleothem aragonite: potential for palaeoenvironmental reconstruction: Earth and Planetary Science Letters, v. 186, p. 255-267, https://doi.org/10.1016 /S0012-821X(01)00253-9.

Fleming, S.W., 2013, A non-uniqueness problem in the identification of power-law spectral scaling for hydroclimatic time series: Hydrological Sciences Journal, v. 59, p. 73-84, https://doi.org/10.1080/02626667.2013.851384.

Fowler, A.M., Boswijk, G., Lorrey, A.M., Gergis, J., Pirie, M., McCloskey, S.P.J., Palmer, J.G., and Wunder, J., 2012, Multi-centennial tree-ring record of ENSOrelated activity in New Zealand: Nature Climate Change, v. 2, p. 172-176, https:// doi.org/10.1038/nclimate1374.

Green, H., Pickering, R., Drysdale, R., Johnson, B.C., Hellstrom, J., and Wallace, M., 2015, Evidence for global teleconnections in a late Pleistocene speleothem record of water balance and vegetation change at Sudwala Cave, South Africa: Quaternary Science Reviews, v. 110, p. 114-130, https://doi.org/10.1016/j.quascirev .2014.11.016.

Holmgren, K., Lee-Thorp, J.A., Cooper, G.R.I., Lundblad, K., Partridge, T.C., Scott, L., Sithaldeen, R., Talma, A.S., and Tyson, P.D., 2003, Persistent millennial-scale climatic variability over the past 25,000 years in Southern Africa: Quaternary Science Reviews, v. 22, p. 2311-2326, https://doi.org/10.1016/S0277-3791(03)00204-X.
Hopley, P.J., Weedon, G.P., Marshall, J.D., Herries, A.I.R., Latham, A.G., and Kuykendall, K.L., 2007, High- and low-latitude orbital forcing of early hominin habitats in South Africa: Earth and Planetary Science Letters, v. 256, p. 419-432, https:// doi.org/10.1016/j.eps1.2007.01.031.

Joussaume, S., et al., 1999, Monsoon changes for 6000 years ago: results of 18 simulations from the Paleoclimate Modeling Intercomparison Project (PMIP): Geophysical Research Letters, v. 26, p. 859-862, https://doi.org/10.1029/1999GL900126.

Kane, R.P., 2009, Periodicities, ENSO effects and trends of some South African rainfall series: An update: South African Journal of Science, v. 105, p. 199-207.

Kosaka, Y., and Xie, S.-P., 2013, Recent global-warming hiatus tied to equatorial Pacific surface cooling: Nature, v. 501, p. 403-407, https://doi.org/10.1038/nature12534

Koutavas, A., and Joanides, S., 2012, El Niño-Southern Oscillation extrema in the Holocene and Last Glacial Maximum: Paleoceanography, v. 27, PA4208, https:// doi.org/10.1029/2012PA002378.

Laepple, T., and Huybers, P., 2014, Global and regional variability in marine surface temperatures: Geophysical Research Letters, v. 41, p. 2528-2534, https://doi.org /10.1002/2014GL059345.

Laskar, J., Robutel, P., Joutel, F., Gastineau, M., Correia, A.C.M., and Levrard, B. 2004, A long-term numerical solution for the insolation quantities of the Earth: Astronomy and Astrophysics, v. 428, p. 261-285, https://doi.org/10.1051/0004 $-6361: 20041335$.

Liu, Z., Lu, Z., Wen, X., Otto-Bliesner, B.L., Timmermann, A., and Cobb, K.M., 2014, Evolution and forcing mechanisms of El Nino over the past 21,000 years: Nature, v. 515, p. 550-553, https://doi.org/10.1038/nature13963.

Moy, C.M., Seltzer, G.O., Rodbell, D.T., and Anderson, D.M., 2002, Variability of El Niño/Southern Oscillation activity at millennial timescales during the Holocene epoch: Nature, v. 420, p. 162-165, https://doi.org/10.1038/nature01194.

Nicholson, S.E., 2000, The nature of rainfall variability over Africa on time scales of decades to millenia: Global and Planetary Change, v. 26, p. 137-158, https://doi .org/10.1016/S0921-8181(00)00040-0.

Rasbury, M., and Aharon, P., 2006, ENSO-controlled rainfall variability records archived in tropical stalagmites from the mid-ocean island of Niue, South Pacific: Geochemistry Geophysics Geosystems, v. 7, p. 4147-4159, https://doi.org/10.1029 12005 GC001232.

Ravelo, A.C., Andreasen, D.H., Lyle, M., Olivarez Lyle, A., and Wara, M.W., 2004, Regional climate shifts caused by gradual global cooling in the Pliocene epoch: Nature, v. 429, p. 263-267, https://doi.org/10.1038/nature02567.

Saji, N.H., Goswami, B.N., Vinayachandran, P.N., and Yamagata, T., 1999, A dipole mode in the tropical Indian Ocean: Nature, v. 401, p. 360-363, https://doi.org $/ 10.1038 / 43854$.

Stevenson, S.L., 2012, Significant changes to ENSO strength and impacts in the twentyfirst century: results from CMIP5: Geophysical Research Letters, v. 39, L17703, https://doi.org/10.1029/2012GL052759.

Sundqvist, H.S., Holmgren, K., Fohlmeister, J., Zhang, Q., Matthews, M.B., Spotl, C., and Kornich, H., 2013, Evidence of a large cooling between 1690 and 1740 AD in southern Africa: Nature: Scientific Reports, v. 3, p. 1767, https://doi.org/10.1038 /srep01767.

Timmermann, A., Lorenz, S.J., An, S.-I., Clement, A., and Xie, S.P., 2007, The effect of orbital forcing on the mean climate and variability of the Tropical Pacific: Journal of Climate, v. 20, p. 4147-4159, https://doi.org/10.1175/JCLI4240.1.

Tudhope, A.W., Chilcott, C.P., McCulloch, M.T., Cook, E.R., Chappell, J., Ellam, R.M., Lea, D.W., Lough, J.M., and Shimmield, G.B., 2001, Variability in the El Niño-Southern Oscillation Through a Glacial-Interglacial Cycle: Science, v. 291, p. 1511-1517, https://doi.org/10.1126/science.1057969.

Turney, C.S.M., Kershaw, A.P., Clemens, S.C., Branch, N., Moss, P.T., and Fifield, K.L., 2004, Millennial and orbital variations of El Niño/Southern Oscillation and high-latitude climate in the last glacial period: Nature, v. 428, p. 306-310, https:// doi.org/10.1038/nature02386.

Wang, P., Clemens, S., Beaufort, L., Braconnot, P., Gabnssen, G., Jian, Z., Kershaw, P., and Sarnthein, M., 2005, Evolution and variability of the Asian monsoon system: State of the art and outstanding issues: Quaternary Science Reviews, v. 24, p. 595-629, https://doi.org/10.1016/j.quascirev.2004.10.002.

Wittenberg, A.T., 2009, Are historical records sufficient to constrain ENSO simulations?: Geophysical Research Letters, v. 36, L12702, https://doi.org/10.1029 /2009GL038710.

Wolff, C., Haug, G.H., Timmermann, A., Damsté, J.S.S., Brauer, A., Sigman, D.M., Cane, M.A., and Verschuren, D., 2011, Reduced interannual rainfall variability in East Africa during the Last Ice Age: Science, v. 333, p. 743-747, https://doi org/10.1126/science. 1203724

Zheng, W., Braconnot, P., Guilyardi, E., Merkel, U., and Yu, Y., 2008, ENSO at 6ka and $21 \mathrm{ka}$ from ocean-atmosphere coupled model simulations: Climate Dynamics, v. 30, p. 745-762, https://doi.org/10.1007/s00382-007-0320-3.

Zinke, J., Dullo, W.-C., Heiss, G.A., and Eisenhauer, A., 2004, ENSO and Indian Ocean subtropical dipole variability is recorded in a coral record off southwest Madagascar for the period 1659 to 1995: Earth and Planetary Science Letters, v. 228, p. 177-194, https://doi.org/10.1016/j.eps1.2004.09.028.

Manuscript received 20 April 2017

Revised manuscript received 11 April 2018

Manuscript accepted 20 June 2018

Printed in USA 